\title{
The Relationship Between the Charter and General Principles: Looking Back and Looking Forward
}

\author{
Emily HANCOX (D)* \\ Selwyn College, Cambridge
}

\begin{abstract}
Article 6 Treaty on European Union sets out two sources of fundamental rights in the EU - the Charter and the general principles of EU law — without specifying a hierarchy between them. Even though the Charter became binding over a decade ago, the Court of Justice of the European Union ('CJEU') is yet to clarify unequivocally how these two sources interact. In this article I argue based upon the relevant legal framework that the Charter ought to replace the general principles it enshrines. This leaves a role for general principles in the incorporation of new and additional rights into the EU legal framework. Such an approach is necessary to ensure that the Charter achieves its aims in enhancing the visibility of the rights protected by EU law, while also providing the impetus for more coherent rights protection within the EU. What an extensive survey of CJEU case law in the field of non-discrimination shows, however, is that the CJEU has struggled to let its general principles case law go, potentially hampering the transformative potential of the Charter.
\end{abstract}

Keywords: Charter, fundamental rights, general principles, discrimination, equal treatment, Article 6 TEU

\section{INTRODUCTION}

When the Charter of Fundamental Rights of the European Union ('Charter') became binding, it entered an already 'crowded house'. ${ }^{1}$ While it provided the EU with a written bill of rights, the Court of Justice of the European Union ('CJEU') had protected fundamental rights via the general principles of Union law since the $1960 \mathrm{~s}^{2}$

* Spencer-Fairest Fellow in Law, Selwyn College, Cambridge. I am most grateful to Kenneth Armstrong, Tobias Lock, and Clara Rauchegger for comments on earlier drafts. I would also like to thank the participants of an E-Coffee at the Institute of European Law, KU Leuven where this article was presented. All errors remain my own. Comments very welcome: eh493@cam.ac.uk.

1 P Cruz Villalón, 'Rights in Europe: The Crowded House' (King's College London Working Papers in European Law, 2012) Working Paper 01/2012.

2 Stauder, 29/69, EU:C:1969:57; Internationale Handelsgesellschaft, 11/70, EU:C:1970:114. 
Taking their inspiration from the 'constitutional traditions common to member states [and] ... international treaties for the protection of human rights', general principles provided an autonomous standard of EU fundamental rights protection. ${ }^{3} \mathrm{Over}$ four decades, the CJEU expanded the range of rights protected and their scope of application. Securing rights in this way attracted praise as a dynamic system of protection complementing national constitutions and the European Convention on Human Rights ('ECHR'). ${ }^{4}$ Development of new rights remained somewhat haphazard, though, with uncertainty surrounding which rights were protected and their scope. Scepticism also endured over the capacity of general principles to 'take rights seriously' on account of their somewhat disingenuous origins in securing the supremacy of EU law and the CJEU's seeming reluctance to scrutinise EU acts with the same intensity as national measures-leading to accusations of a double standard. ${ }^{5}$

The decision to draft a Charter of Fundamental Rights aimed to consolidate much of what had been achieved via general principles; the European Council perceived a need 'to make their overriding importance and relevance more visible to the Union's citizens' as a way of enhancing the EU's legitimacy. ${ }^{6}$ Creating a legally binding bill of rights was thus not the priority. It was enough for the Charter to have declaratory effect and so the European Parliament, the Council, and the Commission 'solemnly proclaimed' the Charter at Nice on 7 December 2000. General principles thus remained the main source of EU fundamental rights protection, with the Charter confined to soft law status.

When the Convention on the Future of Europe set about drafting the Constitutional Treaty, the legal status of the Charter and the continued role for general principles in the protection of fundamental rights came to the fore. If the Charter was to remain declaratory, general principles would continue as the main source of fundamental rights protection. Alternatively, enshrining the Charter within the Constitutional Treaty could potentially render general principles largely superfluous as a source of fundamental rights. ${ }^{7}$

The eventual settlement in the Lisbon Treaty, following the failure of the Constitutional Treaty, opted for a middle ground. Article 6(1) Treaty on European Union ('TEU') bestows binding force upon the Charter by providing that it 'shall have the same legal value as the Treaties'. Without specifying any hierarchy between the sources, Article 6(3) TEU provides that '[f]undamental rights, as guaranteed by the [ECHR] and as they result from the constitutional traditions common to the Member States, shall constitute general principles of the Union's law'. Article 6

\footnotetext{
3 Nold v Commission, 4/73, EU:C:1974:51, para 13.

4 JHH Weiler, 'A Constitution for Europe? Some Hard Choices' (2002) 40 Journal of Common Market Studies 563.

5 J Coppel and A O'Neill, 'The European Court of Justice: Taking Rights Seriously' (1992) 29(4) Common Market Law Review 669.

6 Presidency Conclusions of the Cologne European Council on 4 June 1999.

7 Working Group, 'Modalities and Consequences of Incorporation into the Treaties of the Charter of Fundamental Rights and Accession of the Community/Union to the ECHR', CONV 116/02, pp 7-10.
} 
TEU thus leaves open the relationship between these two sources of fundamental rights. This leaves the CJEU, the authoritative interpreter of EU law, to determine how general principles and the Charter should interact; yet, over a decade has now passed and the CJEU still has not clarified unequivocally the continued role for general principles enshrined in the Charter.

Offering one of the few in-depth assessments of Article $6 \mathrm{TEU},{ }^{8}$ this article starts in Part II by developing four conceivable models for the relationship between the Charter and general principles. While versions of each model can be found in the existing literature, this article makes an important contribution by presenting them as four alternatives and then systematically evaluating each in turn. Each attributes a differing role to the Charter. The first centres general principles as the main source of protection and treats the Charter as declaratory. The second and third envision parallel systems of protection; the former understands the Charter and general principles as equal, whereas the latter treats the Charter as the main source of protection but leaves a residual role for general principles. Importantly, the second and third models see the Charter and general principles as combining to protect the same right, ie a general principle that finds expression in the Charter. The final vision imbues the Charter with transformative potential for rights protection. On this view, the Charter subsumes pre-existing protection and forms the constitutional benchmark henceforth. This leaves open this possibility of recognising new and emerging rights not covered by the Charter as general principles.

I argue that the CJEU ought to adopt the fourth model. The distinctions may seem technical, and each model may in many cases lead to the same outcome, but the choice is of fundamental importance. Only by treating the Charter as the main source of rights protection can it achieve its aim of making rights more visible to the public. Continued reliance on general principles, a judicially developed and methodologically unsound source of Union law, undermines the constitutionally agreed-upon parameters set out in the Charter. Furthermore, only by centring the Charter can there be a transformation in rights protection and the development of a more coherent and searching scrutiny.

Despite the normative importance of treating the Charter as the main source of rights protection, Parts III and IV show that CJEU practice over the past decade does not quite realise this vision. Part III uses Article 21(1) of the Charter prohibiting status discrimination as a case study, chosen as an oft-litigated right with the clear ability to absorb corresponding general principles. The analysis of the relevant case law shows that while the CJEU continues to refer to general principles, it does not assess national or Union rules against both standards. No parallel system emerges as envisaged by the second and third models. However, the CJEU continues to look back to its general principles case law rather than treat the Charter as a break with the past. This hampers its transformative potential.

\footnotetext{
8 See also H Hofmann and BC Mihaescu, 'The Relation between the Charter's Fundamental Rights and the Unwritten General Principles: Good Administration as the Test Case' (2013) 9 European Constitutional Law Review 73; C Amalfitano, General Principles of EU Law and the Protection of Fundamental Rights (Edward Elgar, 2018).
} 
Part IV offers a reflection on when general principles ought to play a role in the protection of fundamental rights. One of the conclusions in Part II is that Article 6(3) TEU authorises the continued recognition of new fundamental rights via general principles. CJEU case law - at least in the field of status discrimination-shows the fine line between the recognition of a new right and the possibility of undermining the constitutional limits in the Charter. The need for clarification on this point cannot be emphasised enough.

\section{COMPETING VISIONS OF THE RELATIONSHIP BETWEEN THE CHARTER AND GENERAL PRINCIPLES}

Part of the difficulty with theorising the relationship between the Charter and general principles, aside from the constructive ambiguity of Article 6 TEU, is that general principles play various roles in the EU legal order; ${ }^{9}$ they fill normative gaps in the Treaties, ${ }^{10}$ condition the legality of secondary Union law, ${ }^{11}$ and act as an aid to the interpretation of written norms. ${ }^{12}$ Their role changes depending on context. It is thus not an easy question to ask what happens to a general principle after codification in written primary law. As Advocate General Mazák reminds us, the answer must be 'sought rather in the Platonic heaven of law than in the law books'. Controversy surrounds the extent to which they persist as independent norms of higher Union law with their use and meaning unaffected by codification in the Charter. $^{14}$

This uncertainty leads to differing interpretations of Article 6 TEU. Depending on how one understands general principles, four models can be distinguished. The following discussion presents and evaluates each model in turn; it argues that only the fourth alternative - treating the Charter as the main source of protection-offers the potential for improved rights protection.

\section{A. The Charter as Declaratory}

One possibility is that the Charter only reinforces and clarifies general principles, which themselves remain the predominant source of rights. ${ }^{15}$ This vision understands general principles as autonomous and self-standing rights in a relationship of hierarchical superiority to the Charter.

\footnotetext{
9 C Semmelmann, 'General Principles in EU Law between a Compensatory Role and an Intrinsic Value' (2013) 19(4) European Law Journal 458.

10 Les Verts, 294/83, EU:C:1986:166, para 23.

11 Bela-Mühle, 114/76, EU:C:1977:96, paras 5-8; Kadi, C-402 and 415/05 P, EU:C:2008:461, paras 283-327.

12 Sturgeon, C-402/07 and C-432/07, EU:C:2009:716, para 48.

13 Opinion of Advocate General Mazák in Palacios de la Villa, C-411/05, EU:C:2007:106, para 86.

14 Ibid, para 135.

15 Proposing a similar solution, see Lord Goldsmith, 'A Charter of Rights, Freedoms and Principles' (2001) 38(5) Common Market Law Review 1201.
} 
Some justification for this view can be found in Article 52(2) of the Charter according to which ' $[\mathrm{r}]$ ights recognised by this Charter for which provision is made in the Treaties shall be exercised under the conditions and within the limits defined by those Treaties'. As general principles find their origins in the Treaties, ${ }^{16}$ one can read '[r]ights recognised by this Charter for which provision is made in the Treaties' as including rights protected as general principles. ${ }^{17}$ Where a Charter right codifies a pre-existing general principle, that Charter right can then be understood as already defined by the Treaties and its interpretation dependent upon that of the corresponding general principle. ${ }^{18}$ This would subjugate the Charter to the general principles it enshrines.

However, the Explanations to the Charter (to which due regard must be had according to Article 52(7) of the Charter) indicate that Article 52(2) of the Charter only concerns Charter rights which explicitly find their origins in the Treaty, ie 'rights which were already expressly guaranteed in the Treaty establishing the European Community and have been recognised in the Charter, and which are now found in the Treaties (notably the rights derived from Union citizenship)' ${ }^{19}$ Interpreting Article 52(2) of the Charter in the manner set out above would also render meaningless the decision to place fundamental rights in a Charter with its own horizontal clauses. Articles 52(3)-(7) of the Charter on the interpretation of rights therein would be robbed of any value since the corresponding general principle would determine the meaning of the Charter. ${ }^{20}$

Article 52(4) of the Charter could also be read as implying a superior role for general principles; it specifies that '[i]n so far as this Charter recognises fundamental rights as they result from the constitutional traditions common to the Member States, those rights shall be interpreted in harmony with those traditions'. As Article 6(3) TEU specifies common constitutional traditions as a source of general principles, the reference could be understood as an indirect reference thereto. ${ }^{21}$ Article 52(4) of the Charter certainly seeks to ensure that the Charter reflects national traditions and keeps pace with evolving conceptions of fundamental rights. It would be a logical jump too far to interpret Article 52(4) of the Charter as tying the interpretation of each Charter right to the corresponding general principle. Article 52(4)

16 The European court of Justice ('ECJ') cites Article 19(1) TEU—specifying that the ECJ 'shall ensure that in the interpretation and application of the Treaties the law is observed' - as authority for the development of general principles, see Brasserie $d u$ Pêcheur, C-46/93 and C-48/93, EU:C:1996:79, para 27.

17 S Peers and S Prechal, 'Scope and Interpretation of Rights and Principles' in S Peers et al (eds), The EU Charter of Fundamental Rights: A Commentary (Hart Publishing, 2014), para 52.93.

18 R Schütze, 'Three "Bills of Rights" for the European Union' (2011) 30(1) Yearbook of European Law 131, p 149.

19 Explanations relating to the Charter of Fundamental Rights [2007] OJ C 303/17, p 33.

20 See note 17 above, para 52.96 .

21 Article 6(3) TEU. The ECJ has explicitly recognised such traditions as inspiring the general principles prohibiting discrimination on grounds of age and sexual orientation. See Mangold, C-144/04, EU:C:2005:709, para 74; Römer, C-147/08, EU:C:2011:286, para 59. 
of the Charter places a qualitatively different obligation on the interpreter from that specified in other Charter provisions, eg where Charter rights are also protected in the ECHR 'the meaning and scope of those rights shall be [at least] the same'. ${ }^{22}$ Harmonious interpretation instead implies congruity with protection across the EU and a reflection of national specificities where appropriate.

\section{B. Parallel Systems of Protection}

The second and third possible models envisage general principles and the Charter as two parallel and self-standing or autonomous sources of fundamental rights which combine to protect the same right.

Differing conceptions of general principles cause the subdivision here. The second possible model does not imply any hierarchy between the two sources of fundamental rights. Where a Charter right and equivalent general principle differ (eg in terms of their personal or material scope), this variant of parallelism contends that they simply combine to maximise rights protection. ${ }^{23}$ While the result of the third model is the same, it differs in its understanding of general principles as inferior to the Charter. Only after establishing that the Charter cannot apply will the CJEU consider the overlapping general principle. ${ }^{24}$ While the general principle remains an independent source of rights it plays a residual role to the Charter.

Essential to understanding both — and the key difference with the fourth model—is the idea of a divergence in relation to the same right. To illustrate, consider how prima facie Article 51(1) of the Charter appeared to narrow the scope of application of EU fundamental rights. Prior to the drafting of the Charter, the CJEU detailed two situations in which general principles bind the Member States: when 'implementing' EU law (eg when transposing a directive into national law) and when acting 'within the scope' of Union law (eg when derogating from free movement rules). ${ }^{25}$ Rather than adopt this wording, Article 51(1) of the Charter specifies that the Charter binds the 'Member States only when they are implementing Union law' (emphasis added). The risk thus emerged that the same right as enshrined in the Charter would apply only to Member State acts implementing EU law, whilst the corresponding general principle applied to the broader category of acts falling within the scope of Union law.

In the end, the CJEU de facto harmonised the scope of the Charter and general principles in Akerberg Fransson by holding that the 'applicability of European

\footnotetext{
22 Article 52(3) of the Charter.

23 See Hofmann and Mihaescu, note 8 above.

24 LS Rossi, 'How Fundamental are Fundamental Principles? Primacy and Fundamental Rights after Lisbon' (2008) 27(1) Yearbook of European Law 65; S Iglesias Sánchez, 'The Court and the Charter: the Impact of the Entry into Force of the Lisbon Treaty on the ECJ's Approach to Fundamental Rights' (2012) 49(5) Common Market Law Review 1565.

25 Wachauf, 5/88, EU:C:1989:321, para 19; ERT, C-260/89, EU:C:1991:254, para 42; Familiapress, C-368/95, EU:C:1997:325, para 24.
} 
Union law entails applicability of the fundamental rights guaranteed by the Charter' ${ }^{26}$ Had the CJEU interpreted Article 51(1) of the Charter narrowly-ie as not encompassing national measures 'within the scope' of Union law-the models discussed here envisage that a Charter right and the general principle it codifies persist as two autonomous standards each with differing applicability; the same substantive right would - depending upon the source-have a different scope of application. For advocates of the pluralistic model, the CJEU should adopt a 'lexical reading' in this situation by going through each source of rights protection in the order listed in Article 6 TEU and layering the different sources to achieve maximal protection. ${ }^{27}$ Whereas those who propose a hierarchical approach, the CJEU should first consider the Charter. Only if the Charter does not apply in the case at hand should the CJEU apply the equivalent general principle. ${ }^{28}$

Parallel systems of protection are perhaps intuitively attractive given their potential to maximise rights protection. Ultimately, however, they ought to be rejected. Maintaining two sources of protection for the same right is damaging to legal certainty, detracts from the constitutional status of the Charter, and contradicts the intentions of the Treaty-framers.

First, a parallel system of protection undermines the express reason for drafting the Charter: to enhance the legitimacy of the EU by making fundamental rights more visible. ${ }^{29}$ According to its Preamble, the Charter aims 'to strengthen the protection of fundamental rights $\ldots$ by making those rights more visible' and 'reaffirms' rights previously protected as general principles. ${ }^{30}$ Accepting a continued role for general principles after their codification detracts from this aim and risks engendering confusion. This is especially so for private actors who, given the horizontal applicability of some fundamental rights, have to comply with the nuances of both regimes. ${ }^{31}$ If general principles and the Charter combine to protect the same right, private actors need to be aware of any overlapping general principle and how it differs from the Charter right. Given the ad hoc judicial development of general principles, it is almost impossible for private actors to gain this knowledge. ${ }^{32}$ Indeed, this was the concern motivating the Danish Supreme Court when it refused to apply the general principle prohibiting discrimination on grounds of age horizontally.

Secondly, maintaining a parallel system of protection enables a judicially developed norm to subvert the limitations agreed upon at a constitutional level. ${ }^{34} \mathrm{~A}$

\footnotetext{
26 Åkerberg Fransson, C-617/10, EU:C:2013:105, para 21.

27 See Hofmann and Mihaescu, note 8 above.

28 See note 24 above.

29 See note 6 above.

30 Recs 4-5.

31 Legal certainty is a general principle of EU law. See Racke, 98/78, EU:C:1979:14, para 20.

32 Opinion of Advocate General Trstenjak in Dominguez, C-282/10, EU:C:2011:559, para 164.

33 Case 15/2014 of the Danish Supreme Court, following DI, C-441/14, EU:C:2016:278.

34 M Dougan, 'The Treaty of Lisbon 2007: Winning Minds, Not Hearts' (2008) 45(3) Common Market Law Review 617, p 664.
} 
deliberative and constitutional process led to the Charter. ${ }^{35}$ The Convention drafting the Charter included a wide range of actors, including representatives of national governments and parliaments, a member of the Commission, and members of the European Parliament, while also inviting individuals and NGOs to comment at public meetings. ${ }^{36}$ Each Member State then had to ratify the Lisbon Treaty (and with it the Charter) before its entry into force. Greater transparency and participation in its adoption imbue the Charter with constitutional significance as an agreement amongst EU citizens as to their fundamental values.

General principles lack similar legitimacy and the time has come to recognise that they fall below the Charter in the hierarchy of norms. The methodology and the threshold for recognition as a general principle of Union law remain unclear; ${ }^{37}$ for instance, when the CJEU recognised a general principle of non-discrimination on grounds of age in Mangold, only two of the (then) 25 Member States (Finland and Portugal) referred to the principle in their constitutions and the principle is not found among the rights of the ECHR.$^{38}$ Distinguishing general principles even further from the Charter, Article 6(1) TEU explicitly grants the Charter 'the same legal value as the Treaties'. By contrast, authority for the development of general principles derives from the Treaties giving them an inherently subsidiary character. Their higher status when compared with secondary Union law largely stems from their normative import. ${ }^{39}$ But a general principle cannot claim a more fundamental status than its written expression on this ground.

Finally, linked to the idea that the Charter aims to replace existing protection via general principles, the drafters did not include Article 6(3) TEU to deal with deficiencies of codified rights. The underlying concern was the need to ensure that the existence of a Charter did not prevent the incorporation of new and emerging fundamental rights within the EU legal order. ${ }^{40}$ Article 6(3) TEU does not address divergences in relation to the same right, but what might instead be termed as substantive gaps.

\footnotetext{
35 S Douglas-Scott, 'The Charter of Fundamental Rights as a Constitutional Document' (2004) 1 European Human Rights Law Review 37.

36 P Craig, EU Administrative Law (Oxford University Press, 2012), p 494.

37 M Herdegen, 'General Principles of EU Law: the Methodological Challenge' in U Bernitz, J Nergelius, and C Cardner (eds), General Principles of EC Law in a Process of Development (Kluwer, 2008), p 346.
}

38 See M Dougan, 'In Defence of Mangold?' in A Arnull et al (eds), A Constitutional Order of States? Essays in EU Law in Honour of Alan Dashwood (Hart Publishing, 2011), pp 220-21 and references cited therein.

39 T Tridimas, The General Principles of EU Law, $2^{\text {nd }}$ ed (Oxford University Press, 2006), p 51; Opinion of Advocate General Trstenjak in Audiolux, C-101/08, ECLI:EU:C:2009:410, para 70. Although the process of discerning which principles are fundamental has been accused of lacking rigour, see eg M Herdegen, 'The Origins and Development of General Principles of Community Law' in B Ulf and J Nergelius (eds), General Principles of European Community Law (Kluwer, 2000), pp 17-21; J Bengoetxea, 'General Principles of EC Law: The Wider European Law and Jurisprudence Debate' (2008) 45(4) CMLRev 1279, p 1280.

40 D Anderson and C Murphy, The Charter of Fundamental Rights: History and Prospects in Post-Lisbon Europe (EUI Working Paper, 2011) LAW No 08, p 7; LF Besselink, 'The Protection of Fundamental Rights Post-Lisbon: The Interaction between the EU Charter of Fundamental Rights, the ECHR and National Constitutions' (2012) Report of 25th FIDE Congress, p 13; T Tridimas, 
Ladenburger-an EU official involved in the drafting of the Charter-notes the perceived utility of the provision 'to clarify that the Court remains free to identify further fundamental rights not enshrined in the Charter. ${ }^{41}$ Supporting Ladenburger's point, the trauvaux préparatoires of the Draft Constitutional Treaty state that what became Article 6(3) TEU only aimed to clarify the possibility for developing additional rights in line with changes in society. ${ }^{42}$ Article 6(3) TEU thus authorises the recognition of additional general principles where it is not possible for the Charter to absorb the new and emerging right.

Relying upon general principles to incorporate new rights into the EU legal order is a wholly legitimate role for general principles going forward. It is qualitatively different from the continued use of general principles codified by the Charter which-as I turn to below-ought to be wholly subsumed by the written norm. One could argue that this use of general principles faces the same criticisms as above, namely that it creates uncertainty and circumvents the decisions of the constitutional legislature to protect only the rights enshrined in the Charter. ${ }^{43}$ However, to adopt this position is to render Article 6(3) TEU essentially meaningless. Instead, one can distinguish the two situations. Relying on a general principle, eg to extend the scope of application of rights enshrined within the Charter directly contradicts Article 51(1) of the Charter. Given that the Charter is silent as to whether it is exhaustive, recognising a new right entails no such conflict. Where the difficulty lies, as Part IV below picks up, is identifying the line between the legitimate recognition of a new right as a general principle and the illegitimate supplementation of a Charter right.

\section{The Charter as the Main Source of Protection}

The fourth possible model treats the Charter as the main source of rights protection, superseding those general principles it now enshrines. Once codified, general principles do not retain an independent existence. Not only does this option avoid the pitfalls of the previous models, it allows for improved rights protection within the EU.

Worth stressing from the outset is that bringing protection 'under one roof' should ensure-at least-parity of protection with the pre-Charter regime. As already emphasised, the Charter aimed to place existing protection on a written footing meaning that the earlier case law on general principles should act as a baseline for interpreting Charter rights. References to earlier case law in the Explanations-to

\section{(F'note continued)}

'Fundamental Rights, General Principles of EU law, and the Charter' (2014) 16 Cambridge Yearbook of European Legal Studies 361, p 377.

41 C Ladenburger, 'Protection of Fundamental Rights Post-Lisbon - The Interaction between the Charter of Fundamental Rights, the European Convention of Human Rights and National Constitutions' (2012) Report of 25th FIDE Congress, $\mathrm{p} 4$.

42 European Convention, 'Commentary on Arts 1-16 of the Preliminary Draft Constitutional Treaty' CONV 528/03, p 13.

43 C Grabenwarter and K Pabel, 'Article 6' in HJ Blanke and S Mangiameli (eds), The Treaty on European Union (TEU): A Commentary (Springer, 2013), pp 333-37. 
which the CJEU must have due regard-reaffirm this point. Continued citation of general principles case law may be necessary for this purpose. When it comes to the future development of rights under the Charter, there is again no reason to assume the Charter cannot provide equal protection to the general principles it enshrines. Articles 52(3) and (4) of the Charter require its interpretation in line with the ECHR and harmoniously with national constitutional traditions-the sources from which general principles 'result'. ${ }^{44}$ Given this close connection between general principles and the Charter in terms of their inspirational sources, one might even presume there will be little need for a parallel system nor much likelihood of this emerging in practice.

Without wanting to jump ahead, it is worth acknowledging that this is borne out in practice. Via interpretation, the CJEU has ensured the contours of the Charter regime are in line with the previous position. Despite initial concerns that the Charter might protect rights in a narrower range of circumstances, the CJEU removed several potential divergences via interpretation. As mentioned above, the interpretation of Article 51(1) of the Charter in Akerberg Fransson removed any potential restrictive effects. ${ }^{45}$ Contrary to predictions that-unlike general principles-the Charter would be capable of only vertical effects ${ }^{46}$ the CJEU confirmed the horizontality of the Charter in Egenberger. ${ }^{47}$ Furthermore, following the short shrift given to the Polish and UK 'opt-outs' (in Protocol No 30) from the Charter in NS, there appears to be no divergence in territorial scope. ${ }^{48}$

That the Charter ensures continuity-in the sense that it does not allow for a weakening of protection-does not mean that the Charter requires continuity. As Frantziou writes, 'a more mature period of rights protection through the Charter requires a conscious break' from the past. ${ }^{49}$ The CJEU's protection of fundamental rights via general principles faced several criticisms. Motivating the CJEU's recognition of general principle as a source of fundamental rights was not a desire to protect the interests enshrined therein, but instead a concern to secure the supremacy and autonomy of EU law. ${ }^{50}$ Escaping this criticism - the use of rights to achieve other

\footnotetext{
44 Article 6(3) TEU.

45 Åkerberg Fransson, note 26 above, para 21.
}

46 AW Heringa and L Verhey, 'The EU Charter: Text and Structure' (2001) 8(1) Maastricht Journal of European and Comparative Law 11, p 21; Opinion of Advocate General Trstenjak in Dominguez, note 32 above, paras 80-83; K Lenaerts, 'Exploring the Limits of the EU Charter of Fundamental Rights' (2012) 8(3) European Constitutional Law Review 375, p 377.

47 Egenberger, C-414/16, EU:C:2018:257, para 79. On the horizontal effect of the Charter, see E Frantziou, 'The Horizontal Effect of the Charter of Fundamental Rights after Egenberger and Bauer' in this symposium.

48 NS, C-411/10 and C-493/10, EU:C:2011:865, para 120. This may differ for rights located in Title IV of the Charter as the ECJ is yet to interpret Article 1(2) of Protocol No 30.

49 E Frantziou, 'The Binding Charter Ten Years on: More than a "Mere Entreaty"?' (2019) 38 Yearbook of European Law 73, p 75.

50 Eg BVerfG, Judgment of 29 May 1974, 37 BvR 271 (Solange I); BVerfG, Judgment of 22 October 1986, 73 BvR 339 (Solange II). See also note 5 above. 
aims - has proved difficult to shake off. ${ }^{51}$ Judicial development of principles also ensured that the CJEU controlled the rights protected-notably few social rightsas well as the standard of protection. Not only did this create uncertainty over which rights were protected, but the CJEU—whose reasoning lacks the rigour perhaps expected of constitutional adjudication ${ }^{52}$ - did not always justify the EU standard in light of the ECHR equivalent. ${ }^{53} \mathrm{~A}$ failure to rationalise fully the intensity of review also led to accusations of a double standard under which the CJEU reviewed national measures with greater stringency than EU acts. ${ }^{54}$ Furthermore, the CJEU did not limit the types of interests that could be weighed against general principles nor elucidate a non-derogable core. ${ }^{55}$ General principles thus lacked the robustness usually expected of constitutional rights, perhaps resulting from concerns about the comparative legitimacy of judicially developed rights and legislative norms. ${ }^{56}$

Treating the Charter as the main source of protection allows the CJEU to outgrow these criticisms. By gathering together existing rights protected variously in the Treaties, legislation, and general principles, the Charter incontrovertibly sets a baseline for the constitutionality of EU action. Any prior source-based distinctions or uncertainties are overcome by presenting the rights therein as 'indivisible'. ${ }^{57}$ Imbuing the Charter with the same status as the Treaties legitimates fundamental rights review and provides the CJEU with the authority to determine permissible limitations and to employ more searching scrutiny. Furthermore, the Charter also paves the way for enhanced constitutional reasoning by imposing certain justificatory requirements on the CJEU. ${ }^{58}$ Article 52(1) of the Charter, for instance, requires that the CJEU determine the 'essence' of each right. ${ }^{59}$ Similarly, Article 52(3) of the Charter ought to lead to greater engagement with the ECHR standard and express justification that the EU standard does in fact match that of the ECHR. An over-

51 A Williams, ‘Taking Values Seriously: Towards a Philosophy of EU Law' (2009) 29(3) Oxford Journal of Legal Studies 549, p 565.

52 For criticism of ECJ reasoning, see T Tridimas, 'The Court of Justice and Judicial Activism' (1996) 21(3) European Law Review 199, p 210.

53 S Douglas-Scott, 'A Tale Of Two Courts: Luxembourg, Strasbourg and the Growing European Human Rights Acquis' (2006) 43 Common Market Law Review 629.

54 See note 5 above and A Clapham, 'A Human Rights Policy for the European Community' (1990) 10 Yearbook of European Law 309, p 331.

55 L Besselink, 'Entrapped by the Maximum Standard: On Fundamental Rights, Pluralism and Subsidiarity in the European Union' (1998) 35(3) Common Market Law Review 629.

56 M Poiares Maduro, 'The Double Constitutional Life of the Charter of Fundamental Rights of the European Union' in T Hervey and J Kenner (eds), Economic and Social Rights under the EU Charter of Fundamental Rights: A Legal Perspective (Hart Publishing, 2002), p 280.

57 Preamble, Rec 2.

58 D Leczykiewicz, “'Constitutional Justice” and Judicial Review of EU Legislative Acts' in D Kochenov, G de Búrca, and A Williams (eds), Europe's Justice Deficit? (Hart Publishing, 2015), p 104.

59 T Tridimas and G Gentile, 'The Essence of Rights: An Unreliable Boundary?' (2019) 20(6) German Law Journal 794. 
emphasis on continuity or the maintenance of a parallel system of protection may prevent any transformative shift. ${ }^{60}$

Based upon the preceding assessment of each possible model, the fourth is clearly preferable. Only by adopting this approach can the CJEU secure legal certainty, respect the express intentions of the constitutional legislature, and improve fundamental rights protection. The best interpretation of Article 6 TEU is thus that it centres the Charter as the main source of rights protection and subsumes the general principles it codifies. Where possible, emerging rights ought to be absorbed within the Charter framework. If not, the recognition of new rights as general principles remains possible as specified by Article 6(3) TEU.

\section{THE RELATIONSHIP BETWEEN THE CHARTER AND GENERAL PRINCIPLES IN PRACTICE}

Using Article 21(1) of the Charter prohibiting status discrimination as a case study, this Part presents an extensive survey of CJEU case law over the past decade and evaluates it in the light of the normative benchmark set out above. The following conclusions emerge. Since the Charter became binding, the CJEU has notunequivocally - adopted the fourth model. The CJEU does not treat codified general principles as a parallel and separate source of right (and so does not adopt the second or third models). While citing prior case law does ensure parity of protection, it also prevents the evolution of a more coherent and rigorous fundamental rights review based on the Charter.

\section{A. Article 21(1) of the Charter and Overlapping General Principles Prohibiting Status Discrimination}

Broadly framed and non-exhaustive, Article 21(1) of the Charter should offer equal -if not greater-protection than corresponding general principles. It should thus be easy for the CJEU to treat Article 21(1) of the Charter as the main source of rights.

According to Article 21(1) of the Charter, '[a]ny discrimination based on any ground such as sex, race, colour, ethnic or social origin, genetic features, language, religion or belief, political or any other opinion, membership of a national minority, property, birth, disability, age or sexual orientation shall be prohibited'. Not all prohibited grounds of discrimination listed in Article 21(1) of the Charter are also general principles of Union law; the CJEU has recognised general principles prohibiting discrimination on the grounds of sex, ${ }^{61}$ age, ${ }^{62}$ and religion. ${ }^{63}$ In relation to other grounds of discrimination prohibited by Article 21(1) of the Charter, the CJEU

\footnotetext{
60 E Frantziou, 'Constitutional Reasoning in the European Union and the Charter of Fundamental Rights: In Search of Public Justification' (2019) 25(2) European Public Law 183.

61 Defrenne III, 149/77, EU:C:1978:130, paras 26-27.

62 Mangold, note 21 above, para 75.

63 Egenberger, note 47 above, para 76.
} 
has shown a reluctance to recognise them specifically as general principles. Instead, the CJEU uses the broad language of principles in cases concerning discrimination on grounds of race and ethnic origin, ${ }^{64}$ sexual orientation, ${ }^{65}$ and disability. ${ }^{66}$ Notably, and a point returned to in Section III.D, many general principles prohibiting status discrimination were recognised after the Charter became binding.

Article 21(1) of the Charter thus extends beyond corresponding general principles. Additionally, it prohibits discrimination on grounds of colour, social origin, genetic features, language, political or any other opinion, membership of a national minority, property, and birth. What is more, the grounds listed in Article 21(1) of the Charter are only indicative, the provision expressly prohibiting '[a]ny discrimination based on any ground such as ...'. Article 21(1) of the Charter thus provides the foundations for developing prohibited grounds of discrimination not listed therein. This would be in line with the European Court of Human Rights' ('ECtHR') case law on Article 14 ECHR, which includes a similar prohibition on discrimination on grounds 'such as ... or other status'. The ECtHR interprets Article 14 ECHR non-exhaustively as including 'differences based on an identifiable, objective or personal characteristic ... not limited to characteristics which are personal in the sense that they are innate or inherent'. ${ }^{67}$

Prohibited grounds of discrimination in Article 21(1) of the Charter, but not recognised as general principles, ought to still be invocable in legal disputes. Inclusion within the Charter, and thus legitimation at a constitutional level, removes the uncertainties of ad hoc development via case law and judicial minimalism over whether a prohibition of discrimination on a particular ground is a general principle ${ }^{68}$ Article 21(1) of the Charter alone provides grounds for invalidating an EU measure discriminating on grounds of eg social origin without the need to also recognise it as a general principle. Any emerging grounds going beyond those explicitly listed in the Charter can be absorbed within Article 21(1) of the Charter given its indicative and non-exhaustive phrasing. This is especially the case since the Explanations to Article 21(1) of the Charter do not tie it to pre-existing case law. Instead, Article 21(1) of the Charter is said to draw upon the legislative basis in Article 19 TFEU, which empowers the Union legislature to 'take appropriate action to combat discrimination based on sex, racial or ethnic origin, religion or belief, disability, age or sexual orientation'.

Linking to the discussion in Part II on the potentiality of the Charter to overcome the criticisms of general principles, it is worth outlining how this might work in the

${ }^{64}$ CHEZ, C-83/14, EU:C:2015:480, para 58; Maniero, C-457/17, EU:C:2018:912, para 36: 'the principle of equality, which is one of the general principles of EU law'.

65 Römer, note 21 above, para 60: a 'principle of non-discrimination on the ground of sexual orientation'.

${ }^{66}$ FOA, C-354/13, EU:C:2014:2463, para 32: a 'general principle of non-discrimination'.

67 Kiyutin v Russia (Application no 2700/10) (2011) 53 EHRR 26, para 56.

68 L Pech, 'Between Judicial Minimalism and Avoidance: The Court of Justice's Sidestepping of Fundamental Constitutional Issues in Römer and Dominguez' (2012) 49(6) Common Market Law Review 1841. 
context of status discrimination. A constitutional prohibition on status discrimination may encourage the CJEU to adopt more rigorous scrutiny of EU acts. In pre-Charter case law, the CJEU merged the content of general principles prohibiting discrimination with that of several directives adopted on the basis of Article 19 TFEU and prohibiting discrimination on grounds of sex, ${ }^{69}$ race, ${ }^{70}$ religion or belief, disability, age, and sexual orientation. ${ }^{71}$ In Defrenne III, for instance, the CJEU held that Ms Defrenne could not rely on the general principle of non-discrimination on grounds of sex since the relevant directive did not cover the time period concerned; in the words of the CJEU 'the [EU] had not, at the time of the events now before the Belgian courts, assumed any responsibility for supervising and guaranteeing the observance of equality between men and women in working conditions other than remuneration'. ${ }^{72}$ Effectively, the relevant directive defined the temporal scope of the general principle. The same can be said of Mangold; even though the CJEU applied the general principle (as the relevant directive could not apply horizontally), the content of the general principle derived wholly from the directive. In the final analysis, when setting out the obligation to disapply national law, the CJEU referred to how '[Union] law and, more particularly, Article 6(1) of Directive 2000/78, must be interpreted as precluding a provision of domestic law such as that at issue in the main proceedings' ${ }^{73}$ Interpreting general principles prohibiting status discrimination in line with overlapping directives deprived them of any independent meaning and prevented them from acting as a check on the legality of those directives. ${ }^{74}$ The Charter should provide the legitimation the CJEU needs to develop an independent constitutional benchmark.

Where the Charter might prompt a further shift is in relation to permissible derogations. As noted above, the CJEU did not control the types of interests that might be weighed against general principles leading to criticisms that general principles lacked the necessary hard edges to protect rights properly. In the field of status discrimination, the CJEU's case law was perhaps not open to such forceful criticism. However, when reviewing EU acts or national measures, the CJEU did not discuss permissible limits on general principles prohibiting status discrimination per se. Whether differential treatment was justified instead depended on what was permitted by the relevant directive. ${ }^{75}$ Otherwise, the CJEU simply employed a test of objective

69 Directive 2006/54/EC on the implementation of the principle of equal opportunities and equal treatment of men and women in matters of employment and occupation (recast) [2006] OJ L204/23.

70 Directive 2000/43/EC implementing the principle of equal treatment between persons irrespective of racial or ethnic origin [2000] OJ L180/22.

71 Directive 2000/78/EC establishing a general framework for equal treatment in employment and occupation [2000] OJ L 303/16.

72 Defrenne III, note 61 above, para 30.

73 Mangold, note 21 above, para 78.

74 C Kilpatrick, 'Non-Discrimination' in S Peers et al (eds), The EU Charter of Fundamental Rights: A Commentary (Hart Publishing, 2014), para 21.61.

75 See eg Hennigs and Mai, C-297/10 and C-298/10, EU:C:2011:560, paras 53-78; Prigge, C-447/09, EU:C:2011:573, paras 37ff; HK Danmark, C-476/11, EU:C:2013:590, paras 45-46. The non- 
justification and looked to whether the difference pursued a permitted aim and was proportionate to that aim. ${ }^{76}$ The Charter might lead to greater constitutional justification here. It includes an independent test for limiting rights—set out in Article 52(1) of the Charter - with several additional requirements including that '[a]ny limitation ... must be provided for by law and respect the essence of those rights and freedoms'. There is the potential for greater reflection on whether all interests can legitimately restrict the prohibition on discrimination and on what core of the right cannot be balanced against other goals.

\section{B. The Charter as the Main Source of Protection}

Since the Charter became binding, the CJEU handed down forty-five decisions concerning status discrimination. ${ }^{77}$ The CJEU resolved thirty-seven cases on the basis of one of the non-discrimination directives finding that the contested national measure: (1) fell within an express derogation; ${ }^{78}$ (2) amounted to discrimination within the scope of the directive $;{ }^{79}$ or (3) did not raise any incompatibility ${ }^{80}$ Given the large

\section{(F'note continued)}

discrimination directives permit indirect discrimination where it is 'objectively justified by a legitimate aim and the means of achieving that aim are appropriate and necessary', but only allow direct discrimination in a far more limited range of situations. Directive 2000/43, note 70 above, Arts 2(2)(b), 4; Directive 2000/78, note 71 above, Arts 2, 4, 6; Directive 2004/113 implementing the principle of equal treatment between men and women in the access to and supply of good and services [2004] OJ L 373/37, Art 2(b); Directive 2006/54, note 69 above, Arts 2(1)(b), 14(2).

76 Eg Arcelor Atlantique, C-127/07, EU:C:2008:728, paras 23ff.

77 Cases were identified by searching the curia.eu database. Searches were carried out, first, by legal provision or act (ie Article 21(1) of the Charter and the non-discrimination directives) and, second, for the following keyword 'principle of non-discrimination'; 'principle of equal treatment'; and 'prohibition on discrimination'. The analysis presented here is limited to cases falling within the temporal scope of the Charter and is up to date as of 15 April 2020.

78 Odar, C-152/11, EU:C:2012:772; Felber, C-529/13, EU:C:2015:20; Ingeniфrforeningen $i$ Danmark, C-515/13, EU:C:2015:115; Salaberria Sorondo, C-258/15, EU:C:2016:873; Parris, C-443/15, EU:C:2016:897; Abercrombie \& Fitch Italia, C-143/16, EU:C:2017:566.

79 Commission v Hungary, C-286/12, EU:C:2012:687; Napoli, C-595/12, EU:C:2014:128; Schmitzer, C-530/13, EU:C:2014:2359; Vital Pérez, C-416/13, EU:C:2014:2371; Starjakob, C-417/13, EU:C:2015:38; Maïstrellis, C-222/14, EU:C:2015:473; Unland, C-20/13, EU:C:2015:561; Ruiz, Conejero, C-270/16, EU:C:2018:17; MB, C-451/16, EU:C:2018:492; Villar Láiz, C-161/18, EU:C:2019:382; Österreichischer Gewerkschaftsbund, C-24/17, EU:C:2019:373; Leitner, C-396/17, EU:C:2019:375; Nobel Plastiques Ibérica, C-397/18, EU:C:2019:703; Commission v Poland, C-192/18, EU:C:2019:924; Instituto Nacional de la Seguridad Social (Complément de pension pour les mères), C-450/18, EU:C:2019:1075; Associazione Avvocatura per i diritti LGBTI, C-507/18, EU:C:2020:289.

80 Tyrolean Airways, C-132/11, EU:C:2012:329; Z, C-363/12, EU:C:2014:159; O, C-432/14, EU:C:2015:643; Plaza Bravo, C-137/15, EU:C:2015:771; Daouidi, C-395/15, EU:C:2016:917; Bowman, C-539/15, EU:C:2016:977; Jyske Finans, EU:C:2017:278; Kleinsteuber, C-354/16, EU:C:2017:539; John, C-46/17, EU:C:2018:131; Stollwitzer, C-482/16, EU:C:2018:180; Maniero, note 64 above; Escribano Vindel, C-49/18, EU:C:2019:106; Horgan and Keegan, C-154/18, EU:C:2019:113; OY v Commission, C-816/18 P, EU:C:2019:486; Land Sachsen-Anhalt, C-773/18, EU:C:2020:125; Comune di Gesturi, C-670/18, EU:C:2020:272; 
number of cases determined on the basis of secondary Union law, the focus here is on the remaining eight cases falling outside their personal or material scope, or concerning the judicial review of Union legislation.

A key finding is that the CJEU continues to refer to both constitutional layers of protection even in cases where a directive is decisive. Only in a minority of cases, although increasingly frequently, does the CJEU refer to Article 21(1) of the Charter alone. ${ }^{81}$ To give an example of the CJEU's usual phrasing, the CJEU refers to 'the principle of non-discrimination on grounds of age, enshrined in Article 21 of the Charter'. ${ }^{82}$ By framing the general principle as 'enshrined in' Article 21(1) of the Charter, the CJEU situates the principle as somehow prior to the Charter.

Importantly, though, a parallel system of protection-heavily criticised in Section II.B above-does not emerge. The CJEU treats the Charter as the applicable norm even when it still mentions the general principle. When assessing the legality of secondary Union law, the CJEU explicitly cites the Charter as the relevant yardstick. In Test-Achats, the CJEU held that since the relevant directive 'expressly refers to Articles 21 and 23 of the Charter, the validity of Article 5(2) of that directive must be assessed in the light of those provisions'. ${ }^{83}$ Similarly in Glatzel and Fries, the CJEU framed the referring question as asking "whether the EU rules at issue in the main proceedings [are] contrary to Article 21(1) of the Charter', ${ }^{84}$ or 'whether [Union secondary law] is valid in the light of ... Article 21(1) of the Charter, 85

In most cases involving the review of national measures, the CJEU is equally resolute that the Charter governs; in Léger, the CJEU starts by examining whether the situation falls within the scope of application of the Charter before specifying that the national measure must respect Article 21(1) of the Charter. ${ }^{86}$ In three cases concerning the horizontal effects of Article 21(1) of the Charter, the CJEU is clear that it is the Charter that applies. Referring to the requirement for national courts to secure 'the judicial protection for individuals flowing from [Article 21(1) of the Charter], ${ }^{87}$ and for national courts 'to guarantee individuals the legal protection afforded to employees under Article 21 of the Charter and to guarantee the full effect of that article'. ${ }^{88}$

\footnotetext{
81 OY v Commission, note 80 above; Villar Láiz, note 79 above; Österreichischer Gewerkschaftsbund, note 79 above; Escribano Vindel, note 80 above; Leitner, note 79 above; Associazione Avvocatura per $i$ diritti LGBTI, note 79 above.

82 Schmitzer, note 79 above, para 22; Vital Pérez, note 79 above, para 25; Felber, note 78 above, para 15; Glatzel, C-356/12, EU:C:2014:350, para 43; Léger, C-528/13, EU:C:2015:288, para 48; Milkova, C-406/15, EU:C:2017:198, para 55; Fries, C-190/16, EU:C:2017:513, para 29; Egenberger, note 47 above, para 76; IR, C-68/17, EU:C:2018:696, para 69; Cresco Investigation, C-193/17, EU:C:2019:43, 76.

83 Test-Achats, C-236/09, EU:C:2011:100, para 17.

84 Glatzel, note 82 above, para 41.

85 Fries, note 82 above, para 27.

86 Léger, note 82 above, paras 46-48.

87 Egenberger, note 47 above, para 79.

88 Cresco Investigation, note 82 above, para 78. See also $I R$, note 82 above, para 71 .
} 
Only in one case, Milkova, is the CJEU's language more equivocal thereby highlighting the need for the CJEU to unambiguously affirm the Charter as the main source of protection. When establishing whether certain national measures complied with EU rules on disability discrimination, the CJEU started by noting that the national measure 'falls within the implementation of EU law within the meaning of Article 51(1) [of the Charter]'. ${ }^{9}$ However, the CJEU then switched to discussing general principles, noting that 'Member States must exercise their discretion [when implementing EU law] in accordance with general principles of EU law' and that 'the national legislation applicable to the main proceedings falls within the implementation of EU law, which means that, in the present case, the general principles of EU law, including the principle of equal treatment, and of the Charter are applicable'. 90 In the end, though, the CJEU refers to the general principle as 'enshrined in' the Charter thereby eliding both sources of protection. Given the potential for uncertainty, the CJEU could be clearer on the role of general principles here.

\section{Continuity with the Pre-Charter Regime}

General principles still play a role in the CJEU's reasoning even if they are not applied independently. As set out in Part II, reference to prior case law will often be necessary to ensure that the Charter offers the same level of protection. In the case law surveyed there were a few such instances. The danger noted was that prior case law becomes not only a minimum but also a maximum standard thereby dampening the Charter's potential to improve EU rights protection. What the post-Lisbon case law on status discrimination shows is that these concerns are justified, if not fully realised. The CJEU still ties the content of Article 21(1) of the Charter to overlapping directives and fails to engage — at least initially-with the additional requirements of the horizontal provisions.

The first point here is that the CJEU draws upon past case law to ensure that no lowering of standards takes place. For instance, in Test-Achats-one of the first cases pre-Charter - the CJEU called on its earlier decision in Arcelor Atlantique to determine when there was a prima facie instance of discrimination. ${ }^{91}$ Drawing on the earlier decision, the CJEU established that 'comparable situations must not be treated differently, and ... that the comparability of situations must be assessed in the light of the subject-matter and purpose of the EU measure which makes the distinction in question'. ${ }^{92}$ Reliance on prior case law in this way makes eminent sense.

Importantly, earlier pronouncements on general principles do not set a maximum standard, ie the CJEU does not limit the meaning of Article 21(1) of the Charter with reference to previous case law. Where the question facing the CJEU has not been the subject of prior judicial consideration, the CJEU develops Article 21(1) of the

\footnotetext{
89 Milkova, note 82 above, para 50.

90 Ibid, paras 53-54.

91 Arcelor Atlantique, note 76 above, paras $23 \mathrm{ff}$.

92 Test-Achats, note 83 above, paras 28-29.
} 
Charter rather than the corresponding general principle. For instance, when in Léger the CJEU discussed restrictions on giving blood for men who have had sex with men for the first time, the general principle prohibiting discrimination on grounds of sexual orientation could provide little assistance. The unwritten nature of general principles means that they are somewhat vague until concretised in case law. As such, the CJEU could not draw upon the general principle but relied directly upon Article 21(1) of the Charter. ${ }^{93}$

Continued reference to pre-Charter case law does mean certain features of the previous regime carry over, though. Breaking up with old habits and modes of reasoning appears hard. This seems to be the case when it comes to developing Article 21(1) of the Charter as an independent constitutional standard. As noted above, pre-Lisbon the CJEU merged the content of general principles prohibiting status discrimination with that of the overlapping directives. Post-Lisbon, the CJEU continues to do this. Apart from Test-Achats, in which the CJEU struck down Directive 2006/54 on account of its incompatibility with Article $21(1)$ of the Charter, ${ }^{94}$ in most cases the CJEU treats the Charter and the corresponding directive as the same. The CJEU frequently reframes the question referred to reflect this point. An oft-repeated formulation is to note that "where they adopt measures which come within the scope of Directive 2000/78 ... the Member States must respect that directive ... it is appropriate to examine the questions raised ... by reference to Directive 2000/78 alone'. ${ }^{95}$ This begs the question whether the focus on secondary Union law comes at the expense of full consideration of the primary law framework. ${ }^{96}$

A further negative spill-over effect concerns the CJEU's failure to engage with the novelties of the Charter framework. One such addition, which-as argued in Section II.C - might lead to closer scrutiny of derogations and enhanced constitutional justification, is Article 52(1) of the Charter. In pre-Charter case law, the CJEU did not distinguish between the content of the general principle and specific legislative exceptions. Otherwise, the CJEU looked to whether any differential treatment was 'objectively justified'. Article 52(1) of the Charter, by contrast, requires the CJEU to check that any proposed restriction is provided for by law, necessary to achieve a legitimate objective, and that it respects the 'essence' of the right.

Early on the CJEU appeared reluctant to change its approach. In Test-Achats, the CJEU did not even mention Article 52(1) of the Charter. Ignoring the additional hurdles imposed by Article 52(1) of the Charter, the CJEU simply used the objective justification test. ${ }^{97}$ Article 52(1) of the Charter is at least cited as the relevant legal test in Glatzel. The referring court questioned the validity of secondary Union law setting out the minimum visual acuity required to drive certain vehicles. When

\footnotetext{
93 Léger, note 82 above, paras 46-48.

94 Test-Achats, note 83 above, para 33.

95 Schmitzer, note 79 above, paras 23-24. See also Tyrolean Airways, note 80 above, paras 22-23; Odar, note 78 above, para 34; Vital Pérez, note 79 above, para 25; Felber, note 78 above, paras 16-17.

96 See A Ward, 'The Impact of the EU Charter of Fundamental Rights on Anti-Discrimination Law: More a Whimper than a Bang?' (2018) 20 Cambridge Yearbook of European Legal Studies 32.

97 Test-Achats, note 83 above, paras 28-30.
} 
assessing the compatibility of the contested directive with the prohibition of discrimination on grounds of disability, the CJEU cited Article 52(1) of the Charter as the relevant justification framework. ${ }^{98}$ Immediately after, however, the CJEU turned to its pre-Charter case law and conflated Article 52(1) of the Charter with the objective justification test. ${ }^{99}$

Fries shows, however, that the Charter might finally be engendering a shift; the CJEU engaged with each stage of Article 52(1) of the Charter systematically. In Fries, an EU regulation prohibited persons over sixty-five years of age acting as commercial air pilots - clearly distinguishing between individuals on grounds of age. In finding the differential treatment justified, the CJEU first noted how-since it stemmed from a regulation - the restriction was provided for by law. ${ }^{100}$ The CJEU then referred to the essence of the prohibition on discrimination and how the limited scope of the restriction meant it did not undermine its 'essential contents' ${ }^{101}$ Finally, the CJEU scrutinised whether the rule aimed to achieve an objective of general interest, was appropriate to reach this goal, and whether it went beyond what was necessary. ${ }^{102}$ Fries shows how following the stages of and engaging with Article 52(1) of the Charter can lead to greater justification of any restrictions on rights. ${ }^{103}$ It thus demonstrates why adopting the fourth model is so important.

\section{The Role of General Principles in Horizontal Cases}

A final issue arising from the case study concerns the use of general principles to create hierarchies between or within Charter rights. An advantage of treating Article 21(1) of the Charter as the main source of rights is that it overcomes uncertainty over whether discrimination is prohibited by a general principle. By presenting the rights contained therein as indivisible, the Charter removes a dependency on judicial recognition for rights protection. Yet in three cases on the horizontal effect of Article 21(1) of the Charter, the CJEU relied upon general principles in a way that potentially undoes this.

Pre-Charter, the CJEU held that general principles can be invoked in cases between private parties. And, in Mangold and Kücükdeveci, the CJEU confirmed that individuals can rely upon the general principle prohibiting discrimination on grounds of age against individuals. ${ }^{104}$ The Charter should now make recourse to general principles in horizontal situations unnecessary. As Advocate General Cruz Villalón put it in Prigge, the prohibition on age discrimination is now "part of a "written constitution"... [and it is] from this source that the possibilities and limitations of

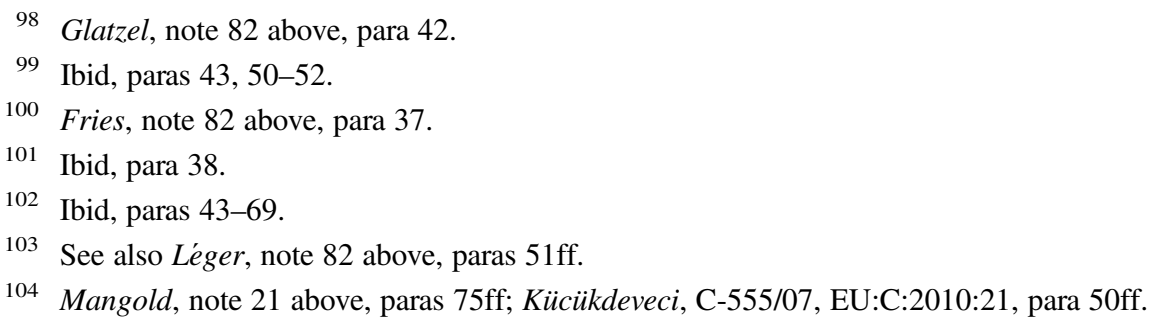


the principle's usefulness must flow'. ${ }^{105}$ The CJEU does not quite follow this approach, though. While the CJEU confirms that Article 21(1) of the Charter can have horizontal effects, it does not reach this conclusion without the help of general principles.

The three cases on horizontal effect concern the prohibition of discrimination on grounds of religion or belief. The CJEU had hinted at a general principle prohibiting discrimination on grounds of religion in the 1976 case of Prais, noting that the defendant did not argue that the "right of freedom of religion as embodied in the European Convention does not form part of the fundamental rights recognized in Community law'. ${ }^{106}$ However, it was not until Egenberger-decided in 2018that the CJEU finally confirmed that it sits among the general principles of Union law. ${ }^{107}$ With the Charter now legally binding this should have been unnecessary and begs the question why recognise a new general principle prohibiting discrimination when such a right is undoubtedly already provided for by the Charter.

The point in each judgment at which the CJEU cites the general principle perhaps provides something of answer here. Immediately before concluding that Article 21(1) of the Charter can apply in disputes between individuals for the first time in Egenberger, the CJEU noted-also for the first time- that ' $[\mathrm{t}]$ he prohibition of all discrimination on grounds of religion or belief is mandatory as a general principle of EU law' ${ }^{108}$ Similarly, the CJEU in IR held that the prohibition of discrimination is 'a mandatory general principle of EU law and is sufficient in itself to confer on individuals a right that they may actually rely on in disputes between them in a field covered by EU law'. ${ }^{109}$ Recognition of, and then reference to, the general principle always prefaces the statement on horizontal effect.

A type of norm combination thus appears to happen in these cases, although it is not explained. One might venture that the general principle is understood as being necessary to bolster the conclusion that Article 21(1) of the Charter is capable of horizontal effects. Qualifying the right as a general principle perhaps reaffirms its existence as part of the laws of the Member States and as part of the fabric of Union law, which then justifies its application in disputes between private parties. What is less evident is whether the horizontal effect of the prohibition of discrimination on grounds of religion or belief in Article 21(1) of the Charter (and thus perhaps other grounds of discrimination listed in Article 21(1) of the Charter) depends upon its recognition as a general principle of Union law. If this is the case it introduces a judicially constructed distinction between the various grounds in Article 21(1) of the Charter. While the CJEU in Bauer did not first recognise the right to annual paid leave as a general principle before concluding that Article 31(2) of the Charter could have horizontal effect, ${ }^{110}$ the need to define Article 21(1) of the Charter as

\footnotetext{
105 Opinion of Advocate General Cruz Villalón in Prigge, C-447/09, EU:C:2011:321, para 26

106 Prais, 130/75, EU:C:1976:142, para 10.

107 Egenberger, note 47 above, para 76.

108 Ibid.

$109 I R$, note 82 above, para 69. Similarly, Cresco Investigation, note 82 above, para 76.

110 Bauer, C-569/16 and C- 570/16, EU:C:2018:871.
} 
an expression of a general principle in these cases implies that it alone lacks the force or justification for horizontal application.

\section{THE DEVELOPMENT OF NEW GENERAL PRINCIPLES}

Where I argue that general principles can still play a role in protecting fundamental rights is as vehicles for incorporating additional fundamental rights into the EU's constitutional framework. ${ }^{111}$ If interpretation of the Charter does not allow for the absorption of a new and emerging right under an existing heading, using general principles can ensure that the Charter does not have a stultifying effect. In theory, delimiting the appropriate use of general principles along these lines ought to be quite simple. But in practice-as the following discussion shows-there is a fine line between identifying a new right and supplementing an existing right (and with which comes the problems of a parallel system warned against above). Without further consideration of this issue, there is a danger that the CJEU destabilises the agreed-upon limits to the Charter under the guise of protecting additional rights.

Article 21(1) of the Charter is non-exhaustive; it prohibits 'discrimination based on any ground such as ...' (emphasis added). Framing Article 21(1) of the Charter in this way means it ought to be able to absorb any emergent prohibitions on status discrimination that transpire in the case law of the ECtHR or in national constitutions. If the CJEU were following the approach propounded in Part II, no gap engaging Article 6(3) TEU and legitimating further general principles ought to emerge in relation to status discrimination. Yet, in the only case post-Lisbon concerning allegations of discrimination on a ground not listed in Article 21(1) of the Charter, the CJEU appears to take a different path. ${ }^{112}$

FOA concerned the decision of a Danish local authority to fire Mr Kaltoft from his post as a childminder. The authority claimed his dismissal resulted from a reduction in the number of children, whereas Mr Kaltoft claimed it was due to his obesity. ${ }^{113}$ The Danish court seized of the dispute asked the CJEU whether 'there is an EU prohibition of discrimination on grounds of obesity' ${ }^{114}$ The CJEU did not start by examining whether the non-exhaustive prohibition in Article 21(1) of the Charter might encompass a prohibition on obesity discrimination. Instead, the CJEU began by considering 'whether EU law must be interpreted as laying down a general principle of non-discrimination on grounds of obesity' ? ${ }^{15}$ Only after answering this question in the negative did the CJEU even consider the Charter. ${ }^{116}$ Rather than

\footnotetext{
111 See Part II.

112 For a pre-Lisbon case, see eg Chacón Navas, C-13/05, EU:C:2006:456 (sickness).

113 FOA, note 66 above, paras 25, 28-29. At the time of his dismissal Mr Kaltoft was obese according to the World Health Organisation's definition.

114 Ibid, para 30.

115 FOA, note 66 above, para 31.

116 Ibid, para 37.
} 
focus on Article 21(1) of the Charter here, the CJEU avoided interpreting the Charter at all by holding that the situation fell outside the scope of Union law. ${ }^{117}$

The CJEU does not explain why it starts by assessing the existence of a general principle, however, the Advocate General is more forthcoming in both his Opinion and in his academic writings. Advocate General Jääskinen argues that the CJEU could not interpret Article 21(1) of the Charter as covering obesity discrimination since this would be 'blocked by the rules that are relevant to the material scope of the EU Charter'. ${ }^{118}$ He supports his position with several provisions of Union law emphasising that the Charter cannot extend the competences of Union law ${ }^{119}$ and with the Explanations to Article 21(1) of the Charter (which state that Article 21(1) of the Charter 'does not alter the extent of powers granted under Article 19 [TFEU] nor the interpretation given to that Article'). Combined, these provisions lead him to conclude that there is an 'outer-boundary of EU fundamental rights' limited by the competences of the EU in the field of discrimination. ${ }^{120}$ While not made explicit, the inevitable conclusion of his argument is that constitutional review under Article 21(1) of the Charter only extends to discrimination on the grounds of sex, racial or ethnic origin, religion or belief, disability, age, or sexual orientation, ie those grounds on which the EU has the competence to legislate.

An element of ambiguity in Advocate General Jääskinen's argument is whether he extends this reasoning to general principles. Given that he mostly supports his position with provisions of or relating to the Charter, one is left guessing whether the development of general principles is so limited. This is an important question and brings to the fore the slippery boundary between the legitimate and illegitimate use of general principles alongside the Charter. If he understands general principles as subject to a differing regime of constitutional limitations, such that recognition of a general principle prohibiting discrimination on grounds of obesity is at least feasible and not similarly, would this amount to the recognition of a new right authorised by Article 6(3) TEU? In one sense, yes; Article 21(1) of the Charter does not explicitly list non-discrimination on grounds of obesity and so recognising a general principle simply fills a gap where there is no corresponding general principle. Yet, in another sense, to recognise a general principle here would be to use a judicially developed norm to escape the constitutionally agreed-upon limits attaching to all Charter rights, ie Article 51(2) of the Charter.

To my mind either analysis is mistaken here. First, the same limitations ought to apply to general principles thereby rendering any gap-filling role impossible.

\footnotetext{
117 Ibid, paras 38-39.

118 N Jääskinen, 'Discrimination on Grounds of Obesity' in S Vogenauer and S Weatherill (eds), General Principles of Law: European and Comparative Perspectives (Hart Publishing, 2017), p 358. See also Opinion of Advocate General Jääskinen in FOA, EU:C:2014:2106, paras 17-19.

119 Article 6(1) TEU, which states that the Charter 'shall not extend in any way the competences of the Union as defined in the Treaties', and Article 51(2) of the Charter, according to which the Charter does not 'establish any new power or task for the Union, or modify powers and tasks as defined in the Treaties'.

120 Opinion of Advocate General Jääskinen in FOA, note 118 above, para 19.
} 
Article 51(2) of the Charter supposedly codifies the CJEU's decision in Grant in which the CJEU refused to reinterpret EU prohibitions on discrimination on grounds of sex as also prohibiting discrimination on grounds of sexual orientation. ${ }^{121}$ Key to the CJEU's reasoning was the contention that general principles 'cannot in themselves have the effect of extending the scope of the Treaty provisions beyond the competences of the Community'. ${ }^{122}$ From a normative standpoint, given the central role of the Charter in defining the scope of constitutional review, even new rights legitimately recognised as general principles ought to be subject to the restrictions on applicability therein such as Articles 51(1) and 52(1) of the Charter.

Secondly, the Advocate General's argument conflates the existence of positive EU competence with the possibility of fundamental rights review. Enshrining a right in the Charter, or indeed recognising a general principle, does not create new legislative competences for the EU. ${ }^{123}$ Instead, fundamental rights provide a benchmark for assessing the legality of EU acts as well as some national acts. Any other interpretation risks reducing huge swathes of the Charter to mere political declarations. In relation to Article 21(1) of the Charter alone it would render aspirational those grounds of discrimination listed in the Charter but not found in Article 19 TFEU (ie colour, ethnic or social origin, genetic features, language, political or any other opinion, membership of a national minority, property). Earlier CJEU case law on Article 51(2) of the Charter appears to reject this consequence and instead relies upon Article 51(2) to aid the interpretation of Article 51(1) on the Charter's scope of application. In $M c B$, for example, the CJEU relied upon Article 51(2) of the Charter to restrict the Charter's application to the relevant national law. Combined application of the two provisions led to the conclusion that 'the Charter should be taken into consideration solely for the purposes of interpreting Regulation No. $2201 / 2003$, and [that] there should be no assessment of national law as such'. ${ }^{124}$ Article 51(2) of the Charter does not change the content of the Charter right but circumscribes its application.

Worryingly, there is some evidence that the CJEU accepts the Advocate General's reasoning, at least on the material scope point. When assessing whether a general principle existed in FOA, the CJEU looked for evidence of EU competence to adopt measures prohibiting obesity discrimination and cited the mainstreaming provision in Article 10 TFEU and the legislative basis in Article 19 TFEU-both of which refer to discrimination only on grounds of sex, racial or ethnic origin, religion or belief, disability, age, or sexual orientation. ${ }^{125}$ Following this, the CJEU assessed each of the directives prohibiting discrimination none of which refer to obesity. ${ }^{126} \mathrm{~A}$

\footnotetext{
121 See note 21 above, p 32.

122 Grant, C-249/96, EU:C:1998:63, para 45.

123 Although as de Búrca notes, it may augment existing competences such as Article 352 TFEU if rights protection is conceived as one of the 'objectives' of the EU. See G de Búrca, 'Human Rights: The Charter and Beyond' (Jean Monnet Working Paper, 2001) Working Paper No 10/01.

$124 M c B$, C-400/10 PPU, EU:C:2010:582, para 52.

125 Ibid, para 33.

126 Ibid, para 36.
} 
similar approach is evident in Jyske Finans. Article 21(1) of the Charter lists 'birth' as a prohibited ground of discrimination, but this is not found in Article 19 TFEU and is not protected by any of the non-discrimination directives. In Jyske Finans, $\mathrm{Mr}$ Huskic - a Danish national - faced additional hurdles to getting a loan when compared with Danish nationals born in the EU because he had been born in a third country. ${ }^{127}$ The national rule leading to such differential treatment implemented an EU directive on money laundering, thereby opening the door for the CJEU to require its application in line with Article 21(1) of the Charter. ${ }^{128}$ However, the CJEU did not even consider this point or the possibility that the national rule led to wrongful discrimination on grounds of birth. ${ }^{129}$ The CJEU's use of positive competences to constrain the interpretation of fundamental rights protection does not appear to differentiate based on source and so may not presage the development of a parallel system of fundamental rights protection. Yet it still appears to adopt an unduly narrow interpretation of the Charter.

\section{CONCLUSION}

When the Charter became binding, it brought with it the potential for a new era of fundamental rights protection in the EU. With the Charter came the possibility of superseding the past criticisms of double standards, of the use of rights to achieve other goals, and of fine-grained distinctions. Collecting together and placing on a constitutional footing all those rights protected by EU law set the scene for the CJEU to finally start 'taking rights seriously'. And yet, this potential has still not been realised.

Over the past decade, the CJEU has avoided any real engagement with the system of fundamental rights protection provided for in Article 6 TEU. The relationship between the Charter and general principles-left open by Article 6 TEU itselfremains uncertain, compounded by the chameleonic nature of general principles. As Part II shows, there are several different possibilities and the potential implications of each option are not always realised. While maintaining two autonomous sources of the same right might seem intuitively attractive, it can create uncertainty, undermine the Charter, and hinder the development of a more coherent system. It is thus of the utmost importance that the CJEU clarifies the central role of the Charter and the residual role for general principles in protecting new and emerging rights.

Looking closely at Article 21(1) of the Charter shows how the CJEU is stuck in a process of transition. In practice, the Charter operates as the main source of protection; the CJEU does not appear to assess EU or national acts against both the Charter and the general principle it codifies. Yet, at the same time, the CJEU is reluctant to make the changes the new Charter framework demands. It continues to interpret the

\footnotetext{
127 Jyske Finans, note 80 above, para 10.

128 Directive 2005/60/EC on the prevention of the use of the financial system for the purpose of money laundering and terrorist financing [2005] OJ L309/15.

129 S Atrey, 'Race Discrimination in EU Law after Jyske Finans' (2018) 55(2) Common Market Law Review 625.
} 
Charter in line with overlapping directives and - at least initially-overlook innovations in the Charter. Using general principles when applying Article 21(1) of the Charter in horizontal situations also implies a new role for general principles; perhaps suggesting a nervousness in the use of the Charter general principles bolster the CJEU's conclusions here. Otherwise, the CJEU's invocation of general principles is perhaps the start of a judicially constructed hierarchy between Charter provisions. One glimmer of hope, however, is that the CJEU is increasingly referring to the Charter alone and to the horizontal clauses therein. One might hope that after a decade, the CJEU is finally looking forward and not looking back when it comes to fundamental rights protection.

General principles will remain a source of fundamental rights, though, and so should not be wholly forgotten. Article 6(3) TEU affirms their role in securing the protection of emerging rights not covered by the Charter. FOA shows how further consideration of exactly when recourse to general principles is legitimate is still very much needed. 